\title{
Pengaruh Kompetensi Sosial dan Kemampuan Menyusun Perangkat Pembelajaran terhadap Kompetensi Pedagogik dan Profesional
}

\author{
Yulia Aulia Rahmah $^{1 \bowtie}$ Budiyono $^{2}$, dan Teguh Wibowo ${ }^{3}$ \\ ${ }^{1,2,3}$ Prodi Pendidikan Matematika, Universitas Muhammadiyah Purworejo
}

\section{Info Artikel}

Sejarah Artikel:

Diterima 24 Juni 2020

Direvisi 19 Nov 2020

Disetujui 20 Nov 2020

Keywords:

Paper type:

Research paper

\begin{abstract}
This study was used to determine the effect of social competence and the ability to compile learning devices on pedagogical and professional competencies of students in the Mathematics Education Study Program. This research leads to the problem of social competence towards pedagogic and professional competence, the ability to develop learning tools towards pedagogic and professional competence. This type of research is associative quantitative. The research was carried out in high school / vocational high school as a place for students of Mathematics Education Study Program FKIP Muhammadiyah University Purworejo 2019/2020. The sample used in this study was 32 students. The method of data collection uses documentation of the value of apprenticeship 1, 2 and 3. Data processing techniques use product moment correlation test and simple regression analysis. As a prerequisite test, normality and homogeneity tests were performed. For the requirements analysis, a significance test and linearity test were performed. The results of this study are (1) there is a positive and significant influence between social competencies on pedagogical and professional competencies; (2) there is a positive and significant influence between the ability to compile learning devices on pedagogical and professional competence.
\end{abstract}

\footnotetext{
Alamat korespondensi:

Program Studi Pendidikan Matematika

Fakultas Keguruan dan Ilmu Pendidikan Universitas Muria Kudus

Kampus UMK Gondangmanis, Bae Kudus Gd. L. 1t I PO. BOX 53 Kudus

Tlp (0291) 438229 ex.147 Fax. (0291) 437198

E-mail: vuliaauliarahmah@gmail.com
}

p-ISSN 2615-4196 e-ISSN 2615-4072 


\section{PENDAHULUAN}

Pada era globalisasi seperti sekarang ini, pendidikan merupakan hal yang sangat penting bagi seluruh negara untuk meningkatkan kualitas dan mutu pendidikan. Warsini (2019) menjelaskan sebagai makhluk sosial manusia tidak dapat dipisahkan dari komunitasnya dan setiap orang tidak dapat berdiri sendiri melakukan segala aktivitas untuk memenuhi kebutuhannya. Akkus \& Karakaya (2020) menjelaskan guru adalah orang yang dapat menerapkan perubahan tersebut untuk membantu siswa beradaptasi dengan kondisi baru di dunia yang terus berubah. Guru adalah figur manusia yang memegang peranan penting dalam meningkatkan kualitas dan mutu pendidikan. Baharuddin (2016) menjelaskan aktivitas belajar mengajar merupakan inti dari proses pendidikan secara keseluruhan, dengan guru sebagai pemegang peranan utama. Dalam kegiatan tersebut, terdapat kegiatan yang mengandung serangkaian aktivitas guru dan siswa atas dasar hubungan timbal balik dalam situasi edukatif untuk mencapai tujuan tertentu. Interaksi antarguru dengan siswa tersebut merupakan syarat utama bagi berlangsungnya proses belajar mengajar.

Pada dasarnya kompetensi merupakan deskripsi yang seharusnya dilakukan seseorang dalam pekerjaannya, sebagaimana yang telah dijabarkan dalam Undang-undang nomor 14 tahun 2005 tentang guru dan dosen pasal 1 ayat (10) yang menyatakan bahwa kompentesi adalah seperangkat pengetahuan, keterampilan, dan perilaku yang harus dimiliki, dihayati dan dikuasai oleh guru dan dosen dalam melaksanakan tugas keprofesionalan. Zulfah \& Layla (2016) menjelaskan kompetensi profesional guru adalah (1) konsep, struktur, dan metode keilmuan/teknologi/seni yang menaungi/ koheren dengan materi ajar; (2) materi ajar yang ada dalam kurikulum sekolah; (3) hubungan konsep antarmata pelajaran terkait; (4) penerapan konsep-konsep keilmuan dalam kehidupan sehari-hari; dan (5) kompetensi secara profesional dalam konteks global dengan tetap melestarikan nilai dan budaya nasional.

Perhatian khusus mengenai pentingnya kompentesi ini, dengan lahirnya Undang-undang No. 14 Tahun 2005 tentang Guru dan Dosen, pada Bab IV pasal 10 dan dalam Peraturan Pemerintah nomor 19 Tahun 2005 tentang standar Nasional Pendidikan pada Bab VI pasal 3 telah menegaskan tentang kompetensi pendidik dan tenaga kependidikan. Kompetensi tersebut meliputi: (1) kompetensi pedagogik, (2) kompetensi kepribadian, (3) kompetensi profesional, dan (4) kompetensi sosial.

Baharuddin (2016) menjelaskan kemajuan yang kompleks dalam pengetahuan ini menuntut guru untuk meningkatkan kualitas belajar mengajar dalam segala permasalahannya agar siswa betul-betul menghayati dan memperoleh manfaat dari apa yang telah dipelajari. Akkus \& Karakaya (2020) menjelaskan struktur pengajaran yang kompleks mulai berkembang jauh sebelum (misalnya, kegiatan pendidikan sebelum sekolah) guru mulai mengajar secara profesional dan berlanjut selama pembelajaran mengajar di universitas dan setelah itu proses belajar mengajar seumur hidup dimulai pada tahun-tahun pertama praktik mengajar yang sebenarnya yang mungkin mencapai tingkat efisiensi dan pematangan tertentu. Syah (2017) menjelaskan setiap calon guru dan guru profesional sangat diharapkan memahami karakteristik (ciri khas) kepribadian dirinya yang diperlukan sebagai panutan para siswanya. Febriana (2019) menjelaskan kompetensi kepribadian sebagai kompetensi personal, yaitu kemampuan pribadi seorang pendidik yang diperlukan agar dapat menjadi pendidik yang baik. Di samping juga harus menampakkan sikap yang baik dan menjadi teladan yang baik bagi siswa.

Dalam sistem dan proses pendidikan, guru tetap memegang peranan penting. Para siswa tidak mungkin belajar sendiri tanpa bimbingan guru yang mampu mengemban tugasnya dengan baik. Abi, dkk (2020) menjelaskan seorang guru yang baik harus dapat mengusai bahan ajar atau materi subjek (konten) dan menguasai ilmu mengajar (pedagogik). Suharto (2017) menjelaskan guru sebagai pendidik profesional wajib memiliki kemampuan pedagogik antara lain pengembangan kurikulum, silabus dan perencanaan pembelajaran dan memiliki kemampuan untuk mewujudkan tujuan pendidikan nasional. Rusna \& Jusriana (2016) menjelaskan kompetensi pedagogik adalah kompetensi guru dalam pengelolaan pembelajaran peserta didik. Utami (2015) menjelaskan kompetensi pedagogik dilihat dari meningkatkan kualitas pembelajaran dan menyiapkan sarana dan prasarana pembelajaran misal media, sumber belajar. Perangkat pembelajaran menjadi pegangan bagi guru dalam melaksanakan pembelajaran baik di kelas. Daryanto \& Aris (2014) menjelaskan perangkat pembelajaran adalah salah satu wujud persiapan yang dilakukan oleh guru sebelum mereka 
melakukan proses pembelajaran. Prastowo (2015) menjelaskan perencanaan yang bagus melibatkan pengalokasian penggunaan waktu, pemilihan isi dan metode pengajaran yang tepat, menciptakan minat siswa, dan membangun lingkungan pembelajaran yang produktif. Guru harus memenuhi persyaratan, profesinya dan berkemauan tinggi untuk mengembangkan potensi siswa secara optimal. Kemampuan yang dituntut terhadap setiap guru adalah kemampuankemampuan yang sejalan dengan peranannya di sekolah.

Ismail, dkk (2018) menjelaskan banyak pihak yang menganggap bahwa rendahnya kualitas pendidikan nasional ini tidak lepas dari minimnya kompetensi yang dimiliki guru. Purwaningrum \& Ahyani (2020) menjelaskan bahwa beberapa guru masih terbiasa mengajar dengan pola teacher centered yang menjadikan siswa tidak dapat mengembangkan berbagai kemampuan matematisnya secara optimal. Dengan demikian, sampai saat ini guru masih memerlukan banyak tambahan pengalaman dalam menerapkan berbagai inovasi pembelajaran.

Ismail, dkk (2018) menjelaskan salah satu indikator bahwa pendidikan belum mampu menghasilkan sumber daya manusia yang berkualitas adalah rendahnya daya saing masyarakat. Dijelaskan bahwa Indeks Pembangunan Manusia Indonesia (IPM) untuk 2015 adalah 0,689. Ismail, dkk (2018) menjelaskan ini menempatkan Indonesia dalam kategori pembangunan manusia menengah, dan peringkat 113 dari 188 negara dan wilayah. Ismail, dkk (2018) menjelaskan nilai IPM meningkat 30,5 persen dari nilai pada tahun 1990. Hal ini mencerminkan kemajuan yang telah dicapai Indonesia dalam hal harapan hidup saat lahir, rata-rata tahun bersekolah, harapan lama bersekolah dan pendapatan nasional bruto (PNB) per kapita selama periode tersebut. Namun demikian IPM Indonesia menurun tajam ke 0,563 (turun 18,2 persen) bila kesenjangan diperhitungkan. Dalam hal ini, Ismail, dkk (2018) pendidikan belum mampu menghasilkan sumber daya manusia yang berkualitas dikarenakan kurangnya kompetensi yang dimiliki guru. Ismail, dkk (2018) menjelaskan hal tersebut kemudian memaksa pemerintah dan lembaga pendidikan untuk memperhatikan kualitas dari pada calon guru. Burgos \& Godino (2020) menjelaskan pentingnya menyelidiki apa yang diajarkan, serta sejauh mana kesalahan pengajaran guru berdampak pada pembelajaran siswa.
Dalam hal ini, mahasiswa Fakultas Keguruan dan Ilmu Pendidikan (FKIP) Universitas Muhammadiyah Purworejo sebagai calon guru harus memiliki kompetensi pendidik dan tenaga kependidikan. Setiap siswa yang belajar pada umumnya memiliki taraf perkembangan yang berbeda, sehingga menuntut materi, metode, dan pendekatan yang berbeda. Dengan adanya program magang yang diadakan Universitas Muhammadiyah Purworejo untuk mendukung dan mendorong pengembangan calon guru yang profesional dengan bertujuan membangun jati diri pendidik, memantapkan kompetensi akademik kependidikan dan memantapkan kemampuan awal guru dalam mengembangkan perangkat pembelajaran, serta memberikan pengalaman awal tambahan sesuai dengan kewenangan tambahan yang akan diberikan kepada calon guru dapat tercapai sesuai dengan tujuan yang telah ditentukan. Sehingga mahasiswa Fakultas Keguruan dan Ilmu Pendidikan (FKIP) sebagai calon guru harus memiliki kompetensi yaitu kepribadian, sosial, pedagogik, profesional dan memahami hal yang harus disiapkan oleh guru.

Melihat latar belakang masalah dari Ismail, dkk (2018) menjelaskan salah satu indikator bahwa pendidikan belum mampu menghasilkan sumber daya manusia yang berkualitas adalah rendahnya daya saing masyarakat maka peneliti akan melakukan penelitian yang bertujuan untuk mengetahui adakah pengaruh kompetensi sosial dan kemampuan menyusun perangkat pembelajaran terhadap kompetensi pedagogik dan profesional mahasiswa Program Studi Pendidikan Matematika.

\section{METODE PENELITIAN}

Penelitian ini dilakukan dengan metode kuantitatif menggunakan analisis regresi linier sederhana dengan uji prasyarat menggunakan uji korelasi product moment. Bentuk dari paradigma penelitian disajikan dalam Gambar 1 berikut.

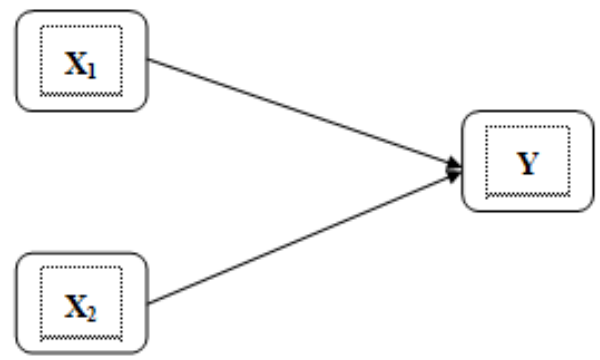

Gambar 1. Pradigma Penelitian 
Keterangan:

$\mathrm{X}_{1}=$ Kompetensi Sosial

$\mathrm{X}_{2}=$ Kemampuan Menyusun Perangkat

Pembelajaran

$\mathrm{Y}=$ Kompetensi Pedagogik dan Profesional

Penelitian dilaksanakan di SMA/SMK

sebagai tempat Magang Mahasiswa Program Studi Pendidikan Matematika FKIP Universitas Muhammadiyah Purworejo 2019/2020. Sekolah yang digunakan magang untuk penelitian yaitu 52 SMA/SMK Negeri dan SMA/SMK Swasta dari Purworejo, Kebumen, Cilacap, Magelang dan Wonosobo. Adapun metode penentuan sampel menggunakan Simple Random Sampling, yakni mahasiswa magang 1, 2 dan 3 angkatan 2016 Program Studi Pendidikan Matematika Universitas Muhammadiyah Purworejo dengan jumlah sampel 32 mahasiswa. Metode pengumpulan data menggunakan dokumentasi dari nilai magang 1, 2 dan 3 . Analisis data yang digunakan adalah uji korelasi product moment dan analisis regresi sederhana. Uji korelasi product moment digunakan untuk mengetahui hubungan antar variabel sebelum melakukan analisis regresi sederhana. uji prasyaratnya menggunakan uji normalitas dan uji homogenitas. Untuk persyaratan analisis regresi sederhana yaitu uji linearitas dan uji keberartian.

\section{HASIL DAN PEMBAHASAN}

Penelitian ini bertujuan untuk mengetahui pengaruh kompetensi sosial dan kemampuan menyusun perangkat pembelajaran mahasiswa Fakultas Keguruan dan Ilmu Pendidikan (FKIP) terhadap kompetensi pedagogik dan profesional. Penelitian ini dilakukan di Program Studi Pendidikan Matematika Fakultas Keguruan dan Ilmu Pendidikan (FKIP) Universitas Muhammadiyah Purworejo dengan jumlah populasi 101 mahasiswa dan sampel 32 mahasiswa. Pengumpulan data dalam penelitian ini menggunakan dokumentasi dengan hasil nilai Magang 1, Magang 2 dan Magang 3. Nilai kompetensi sosial dari nilai Magang 1, Nilai Kemampuan Menyusun Perangkat Pembelajaran dari nilai Magang 2 dan nilai kompetensi pedagogik dan profesional dari nilai Magang 3.

Dari data yang sudah ada selanjutnya disajikan dalam bentuk tabel distribusi frekuensi data bergolong. Penyajian data dalam bentuk distribusi frekuensi kompetensi sosial, kemampuan menyusun perangkat pembelajaran, kompotensi pedagogik dan profesional. Untuk penyajian data nilai kompetensi sosial dalam bentuk distribusi frekuensi data bergolong disajikan dalam Tabel 1 berikut.Pembahasan harus terfokus pada hasil dan bagaimana hasil tersebut dapat menjawab masalah yang diangkat.

Tabel 1. Distribusi Frekuensi Nilai Kompetensi Sosial

\begin{tabular}{lll}
\hline No & Data & Frekuensi \\
\hline 1 & $77-79$ & 2 \\
2 & $80-82$ & 6 \\
3 & $83-85$ & 3 \\
4 & $86-88$ & 14 \\
5 & $89-91$ & 5 \\
6 & $92-94$ & 2 \\
& Jumlah & 32 \\
\hline
\end{tabular}

Tabel 2. Distribusi Frekuensi Nilai Kemampuan Menyusun Perangkat Pembelajaran

\begin{tabular}{lll}
\hline No & Data & Frekuensi \\
\hline 1 & $77-79$ & 2 \\
2 & $80-82$ & 6 \\
3 & $83-85$ & 3 \\
4 & $86-88$ & 14 \\
5 & $89-91$ & 5 \\
6 & $92-94$ & 2 \\
& Jumlah & 32 \\
\hline
\end{tabular}

Tabel 3. Distribusi Frekuensi Nilai Kompetensi Pedagogik dan Profesional

\begin{tabular}{lll}
\hline No & Data & Frekuensi \\
\hline 1 & $76-78$ & 3 \\
2 & $79-81$ & 5 \\
3 & $82-84$ & 4 \\
4 & $85-87$ & 12 \\
5 & $88-90$ & 4 \\
6 & $91-93$ & 4 \\
& Jumlah & 32 \\
\hline
\end{tabular}

Dari Tabel 1, 2, dan 3 diperoleh rerata, variansi dan standar deviasi. Rerata, variansi dan standar deviasi masing-masing nilai tersebut disajikan dalam Tabel 4 berikut.

Tabel 4. Rerata, Variansi dan Standar Deviasi Kompetensi Sosial, Kemampuan Menyusun Perangkat Pembelajaran dan Kompetensi Pedagogik dan Profesional

\begin{tabular}{llll}
\hline $\begin{array}{l}\text { Statis } \\
\text { tik }\end{array}$ & $\begin{array}{l}\text { Kompe } \\
\text { tensi } \\
\text { Sosial }\end{array}$ & $\begin{array}{l}\text { Kemampuan } \\
\text { menyusun } \\
\text { Perangkat } \\
\text { Pembelajaran }\end{array}$ & $\begin{array}{l}\text { Kompetensi } \\
\text { Pedagogik } \\
\text { dan } \\
\text { Profesional }\end{array}$ \\
\hline $\bar{X}$ & 85,88 & 83,84 & 84,97 \\
$\mathrm{~s}^{2}$ & 15,33 & 15,81 & 19,52 \\
$\mathrm{~S}$ & 3,94 & 3,98 & 4,42 \\
\hline
\end{tabular}

Dalam penelitian ini dilakukan analisis data yang bertujuan untuk menjawab hipotesis 
yang telah ada. Analisis data yang dilakukan adalah pengujian prasyarat dan pengujian hipotesis. Pengujian prasyarat meliputi uji normalitas dan uji homogenitas.

a. Uji Normalitas

1) Pengujian Normalitas Kompetensi Sosial

Statistika uji yang digunakan adalah Chi Kuadrat dihitung secara manual. Berdasarkan perhitungan diperoleh $X$ ${ }^{2}$ hitung selanjutnya dibandingkan dengan $X$ ${ }_{\text {tabel }}$, karena $6,79<11,07$. Hal ini menunjukkan data sampel variabel kompetensi sosial berasal dari populasi berdistribusi normal.

2) Pengujian Normalitas Kemampuan Menyusun Perangkat Pembelajaran

Statistika uji yang digunakan adalah Chi Kuadrat dihitung secara manual. Berdasarkan perhitungan diperoleh $X$ ${ }^{2}$ hitung selanjutnya dibandingkan dengan $X$ $2_{\text {tabel }}$, karena $8,91<11,07$. Hal ini menunjukkan data sampel variabel kemampuan menyusun perangkat pembelajaran berasal dari populasi berdistribusi normal.

3) Pengujian Normalitas Kompetensi Pedagogik dan Profesional

Statistika uji yang digunakan adalah Chi Kuadrat dihitung secara manual. Berdasarkan perhitungan diperoleh $\mathrm{X}$ ${ }^{2}$ hitung selanjutnya dibandingkan dengan X 2tabel , karena 5,69 < 11,07. Hal ini menunjukkan data sampel variabel kompetensi pedagogik dan profesional berasal dari populasi berdistribusi normal.

b. Uji Homogenitas

1) Pengujian Homogenitas Kompetensi Sosial dengan Kompetensi Kemampuan Menyusun Perangkat Pembelajaran

Statistika uji yang digunakan adalah Uji F dihitung secara manual. Dengan milihat nilai variansi dari ketiga variabel pada Tabel 4. Berdasarkan perhitungan diperoleh $F_{\text {hitung }}=1,03$ dan $F_{\text {hitung }}$ selanjutnya dibandingkan dengan $F_{\text {tabel }}$, karena $1,03<1,84$. Hal ini menunjukkan data sampel berasal dari variansi populasi homogen.

2) Pengujian Homogenitas Kompetensi Sosial dengan Kompetensi Pedagogik dan Profesional

Statistika uji yang digunakan adalah Uji F dihitung secara manual. Dengan milihat nilai variansi dari ketiga variabel pada Tabel 4. Berdasarkan perhitungan diperoleh $F_{\text {hitung }}=1,27$ dan $F_{\text {hitung }}$ selanjutnya dibandingkan dengan $F_{\text {tabel }}$, karena $1,27<1,84$. Hal ini menunjukkan data sampel berasal dari variansi populasi homogen.

3) Pengujian Homogenitas Kemampuan Menyusun Perangkat Pembelajaran dengan Kompetensi Pedagogik dan Profesional

Statistika uji yang digunakan adalah Uji F dihitung secara manual. Dengan milihat nilai variansi dari ketiga variabel pada Tabel 4. Berdasarkan perhitungan diperoleh $F_{\text {hitung }}=1,24$ dan Fhitung selanjutnya dibandingkan dengan $\mathrm{F}_{\text {tabel }}$, karena $1,24<1,84$. Hal ini menunjukkan data sampel berasal dari variansi populasi homogen.

Setelah dilakukan pengujian normalitas dan homogenitas diketahui bahwa data berdistribusi normal dan homogen maka statistik parametris dapat digunakan. Statistik parametris yang digunakan adalah korelasi product moment. 1) Hasil perhitungan pengujian pengaruh kompetensi sosial terhadap kompetensi pedagogik dan profesional adalah sebagai berikut.

Persamaan regresi linear sederhana, berdasarkan perhitungan, diperoleh harga $\mathrm{a}=$ 51,52 dan $\mathrm{b}=0,39$. Maka persamaan regresi linear sederhana diperoleh $\mathrm{Y}^{\wedge}=51,52+0,39 \mathrm{X}$, $\mathrm{t}_{\text {hitung }}=2,11$ dan $r_{y x_{2}}=0,36$. Berdasarkan nilai

dari korelasi, ternyata hubungan antara variabel tergolong rendah. $t_{\text {hitung }}$ selanjutnya dibandingkan dengan $\mathrm{t}_{\text {tabel }}$ dengan taraf kesalahan $(\alpha)=5 \%$, dk $=31$ maka $_{\text {tabel }}=2,021$ karena 2,11>2,021. Hal ini menunjukkan ada pengaruh positif dan signifikan antara kompetensi sosial dengan kompetensi pedagogik dan profesional.

Untuk uji prasyarat dari uji linearitas, berdasarkan perhitungan diperoleh $F_{\text {hitung }}=0,41$ dan $F_{\text {hitung }}$ selanjutnya dibandingkan dengan $F_{\text {tabel }}$ dengan taraf kesalahan $(\alpha)=5 \%$, dk pembilang 10 , dk penyebut 20 maka $F_{\text {tabel }}=2,35$ karena $0,41<2,35$. Hal ini menunjukkan hubungan antara kompetensi sosial dengan kompetensi pedagogik dan profesional adalah linear.

Untuk uji prasyarat dari uji keberartian, berdasarkan perhitungan diperoleh $F_{\text {hitung }}=4,38$ dan $F_{\text {hitung }}$ selanjutnya dibandingkan dengan $F_{\text {tabel }}$ dengan taraf kesalahan $(\alpha)=5 \%$, dk pembilang 1 , dk penyebut 30 maka $F_{\text {tabel }}=4,17$ karena 4,38 > 4,17. Hal ini menunjukkan hubungan antara kompetensi sosial dengan kompetensi pedagogik dan profesional adalah berarti. 
Dalam hal ini menunjukkan terdapat pengaruh positif dan signifikan antara kompetensi sosial dengan kompetensi pedagogik dan profesional dengan koefisien arah regresi berarti dan linear. Pada penelitian ini juga diperoleh hasil yang sama dengan penelitianpenelitian sebelumnya (Yofi \& Margaretha, 2018) yang menunjukkan bahwa kompetensi sosial berpengaruh signifikan terhadap kompetensi pedagogik dan profesional.

2) Hasil perhitungan pengujian pengaruh kemampuan menyusun perangkat pembelajaran terhadap kompetensi pedagogik dan profesional adalah sebagai berikut.

Persamaan regresi linear sederhana, berdasarkan perhitungan, diperoleh harga $\mathrm{a}=$ 25,49 dan $b=0,71$. Maka persamaan regresi linear sederhana diperoleh $\mathrm{Y}^{\wedge}=25,49+0,71 \mathrm{X}$, thitung = 4,94 dan $\mathrm{r}_{-}\left(\llbracket \mathrm{yx} \rrbracket \_3\right)=0,67$. Berdasarkan nilai dari korelasi, ternyata hubungan antara variabel tergolong kuat. thitung selanjutnya dibandingkan dengan ttabel dengan taraf kesalahan $(\alpha)=5 \%, \mathrm{dk}=31$ maka ttabel $=$ 2,021 karena 4,94 > 2,021 maka H0 ditolak. Hal ini menunjukkan ada pengaruh positif atau signifikan antara kemampuan menyusun perangkat pembelajaran dengan kompetensi pedagogik dan profesional.

Untuk uji prasyarat dari uji linearitas, berdasarkan perhitungan diperoleh Fhitung = 0,46 dan Fhitung selanjutnya dibandingkan dengan Ftabel dengan taraf kesalahan $(\alpha)=5 \%$, $\mathrm{dk}$ pembilang 10 , dk penyebut 20 maka Ftabel = 2,35 karena $0,46<2,35$. Hal ini menunjukkan hubungan antara kemampuan menyusun perangkat pembelajaran dengan kompetensi pedagogik dan profesional adalah linear.

Untuk uji prasyarat dari uji keberartian, berdasarkan perhitungan diperoleh Fhitung = 24,88 dan Fhitung selanjutnya dibandingkan dengan Ftabel dengan taraf kesa-lahan $(\alpha)=5 \%$, $\mathrm{dk}$ pembilang 1 , dk penyebut 30 maka Ftabel = 4,17 karena 24,88 > 4,17. Hal ini menunjukkan hubungan antara kemampuan menyusun perangkat pembelajaran dengan kompetensi pedagogik dan profesional adalah berarti.

Dalam hal ini menunjukkan terdapat pengaruh positif atau signifikan antara kemampuan menyusun perangkat pembelajaran dengan kompetensi pedagogik dan profesional dengan koefisien arah regresi berarti dan linear. Pada penelitian ini juga diperoleh hasil yang sama dengan penelitian-penelitian sebelumnya (Yofi \& Margaretha, 2018) yang menunjukkan bahwa kemampuan menyusun perangkat pembelajaran berpengaruh signifikan terhadap kompetensi pedagogik dan profesional. Kompetensi tersebut sangat diperlukan dalam pengembangan Higher Order Thingking Skills (HOTS) dalam pembelajaran sebagai wujud pengimplementasian kurikulum 2013 (Badjeber \& Purwaningrum, 2018).

\section{SIMPULAN}

Dari pengolahan dan pembahasan data, peneliti dapat mengambil kesimpulan sebagai berikut.

1) Terdapat pengaruh positif dan signifikan antara kompetensi sosial terhadap kompetensi pedagogik dan profesional pada mahasiswa Program Studi Pendidikan Matematika Fakultas Keguruan dan Ilmu Pendidikan (FKIP) Universitas Muhammadiyah Purworejo.

2) Terdapat pengaruh positif dan signifikan antara kemampuan menyusun perangkat pembelajaran terhadap kompetensi pedagogik dan profesional pada mahasiswa Program Studi Pendidikan Matematika Fakultas Keguruan dan Ilmu Pendidikan (FKIP) Universitas Muhammadiyah Purworejo.

3) Tinggi rendahnya nilai dari kompetensi sosial dan kemampuan menyusun perangkat pembelajaran mempengaruhi nilai dari kompetensi pedagogik dan profesional.

\section{DAFTAR PUSTAKA}

Abi, A. M., Mampouw, H. L., \& Ratu, N. 2020. Deskripsi Pedagogical Content Knowledge Guru pada Bahasan tentang Pola Bilangan. Jurnal Ilmiah Pendidikan Matematika, 3(1): 43-50.

Akkus, R., \& Karakaya, M. 2020. The Effects of the Professional Development Program Supported by On-the-job Visits on the Pedagogies of Mathematics Teachers. International Electronic Journal of Mathematics Education, 15 (3): 1-17.

Badjeber, R \& Purwaningrum, J. P. 2018. Pengembangan Higher Order Thinking Skills dalam Pembelajaran Matematika di SMP. Guru Tua: Jurnal Pendidikan dan Pembelajaran, 1(1): 36-43

Baharuddin. 2016. Pendidikan \& Psikologi Perkembangan. Jogjakarta: Ar-Ruzz Media.

Burgos, M., \& Godino, J.D. 2020. Semiotic Conflicts in the Learning of Proportionality: Analysis of a Teaching Experience in Primary Education. International Electronic Journal of Mathematics Education, 15 (3): 1-18. 
Daryanto. \& Aris D. 2014. Pengembangan Perangkat Pembelajaran (Silabus, RPP, PHB, Bahan Ajar) Yogyakarta: Gava Media.

Depdiknas. 2005. Undang-Undang RI No. 14 Tahun 2005 tentang Guru dan Dosen. Jakarta: Departemen Pendidikan Nasional.

Fathorrahman. 2017. Kompetensi Pedagogik, Profesional, Kepribadian, dan Kompetensi Sosial Dosen. Akademika, 15(1): 1-6.

Febriana, R. 2019. Kompetensi Guru. Jakarta: Bumi Aksara.

Ismail, I., Hasan, H., \& Musdalifah. 2018. Pengembangan Kompetensi Mahasiswa Melalui Efektivitas Program Magang Kependidikan. Jurnal Pengabdian Masyarakat Massenrempulu, 2(1): 8-17.

Prastowo, A. 2015. Menyusun Rencana Pelaksanaan Pembelajaran (RPP) Tematik Terpadu Implementasi Kurikulum 2013 untuk SD/MI. Jakarta: Prenadamedia Group.

Purwaningrum, J. P. \& Ahyani, L. N. 2020. Pelatihan Pembuatan dan Penggunaan Alat Peraga Matematika pada Materi Luas Daerah Belah Ketupat dengan Pendekatan Luas Daerah Segitiga. Selarapang: Jurnal Pengabdian Masyarakat Berkemajuan, 4(1): 244-250.

Rusna, A. S., \& Jusriana, A. 2016. Hubungan Kompetensi Kepribadian dengan
Kompetensi Pedagogik Guru Fisika Madrasah Aliyah Kota Makassar. Jurnal Pendidikan Fisika, 4(2): 75-82.

Suharto. 2017. Kemampuan Guru Dalam Mengembangkan Perangkat Pembelajaran IPS Berbasis Karakter (Studi Pada Guru SMK Negeri 3 Geger Madiun). Jurnal Studi Sosial, 2(2): 116-129.

Syah, M. 2017. Psikologi Pendidikan. Bandung: PT Remaja Rosdakarya.

Utami, B. 2015. Pelaksanaan Magang Profesi Kependidikan Mahasiswa Pendidikan Kimia FKIP UNS. Prosiding Seminar Nasional Pendidikan Sains (SNPS) 2015, 336-343.

Warsini, A. 2019. Penerapan Model TAI untuk Meningkatkan Kemampuan Kerjasama dan Hasil Belajar Matematika Materi Barisan dan Deret Kelas IXC SMP Negeri 4 Sumbang Semester 2 Tahun Pelajaran 2017/2018. Journal of Mathematics Education, 5(2): 9-14.

Yovi A. L., \& Margaretha P. 2018. Hubungan Kompetensi Pedagogik, Profesional, Sosial, dan Kepribadian pada Guru Sekolah Nnformal X. Jurnal Kependidikan, 2(1): 197-208.

Zulfah., dan Layla N. 2016. 99,9\% Lulus Uji Kompetensi Guru (UKG). Yogyakarta: Bright Publisher. 